\title{
Elderly and dietary supplements: Benefits and Risks
}

\author{
Katja Kramberger, Darja Barlič-Maganja \\ University of Primorska, Faculty of Health Sciences, Izola, Slovenia \\ katja.kramberger@fvz.upr.si, darja.maganja@fvz.upr.si
}

\section{Abstract}

Introduction: A large percentage of older adults do not receive recommended amounts of many nutrients from food alone. Due to increased awareness of the importance of nutrition to health, along with the advertising and over-the-counter accessibility of the dietary supplements, their use is increasing among the elderly. The purpose of this review is to determine the major benefits of dietary supplementation specific to older adults, as well as to highlight the potential risks that may occur with their use. Methods: PubMed database and the world wide web were searched with mesh terms "prehranska dopolnila" »dietary/food supplements«, »starostniki« - »elderly«, »zakonodaja« - »legislation«, »interakcije« - »interactions« and their combinations. English language articles published after 2000 were included in narrative review, as well as electronic sources regarding legislation in Slovenia and Europe. Results and discussion: Under certain circumstances, i.e. nutrient deficiencies, older adults may benefit from supplementation. Clinical studies have indicated a possible reduction in the risk of developing age-related diseases among older people who reported long-term use of multivitamin supplements. Higher plasma levels of omega-3 polyunsaturated fatty acids have also been associated with fewer cardiovascular deaths in older people taking omega-3 supplements. Dietary protein supplementation combined with physical activity had a strong effect in preventing age-related muscle mass attenuation and leg strength loss in older people. Finally, beneficial effects of purified flavonoids on cognitive function have been reported in some studies. Although there are potential benefits to taking supplements, there are also potential drawbacks. In addition to the increased risk of nutrient overdose, concomitant use of dietary supplements and prescription medications is common in this population and can increase the risk for drug-nutrient interactions and adverse events. Particular caution 
should be taken when using herbal supplements containing St. John's Wort, grapefruit, pomegranate, or black pepper, as these can affect the metabolism of numerous drugs. Supplements containing cranberry, Ginkgo, garlic, coenzyme Q10, or omega-3 fatty acids, on the other hand, may increase the risk of bleeding when used together with anticoagulant medications.

Conclusion: Given the risks associated with dietary supplement use, decisions about the appropriateness of supplementation for older adults should be made by healthcare providers, who should work with patients to identify quality products and evaluate the benefits and risks of supplement use on a case-by-case basis.

Keywords: dietary supplements, elderly, indications, interactions

\section{Introduction}

Diet is known to play an important role in the prevention of many diseases, and the right choice of nutrients can help prevent them and improve quality of life. However, analysis of nationwide survey data has shown that a large percentage of older adults do not receive recommended amounts of many nutrients from food alone (Walrand, 2018). This is of particular concern because conditions prevalent in this population, can further compromise nutritional status and could have a negative impact on neurological and cardiovascular health, mood, immune function, vision, blood sugar control, and bone strength (Harris et al., 2017; Walrand, 2018). The main reasons for nutrient deficiencies and risk of malnutrition among the older adult population, can result from loss of appetite with aging, decreased oral intake, chewing or swallowing difficulty, and/or nutrient depletions from medication use, among many other social and medical factors (Harris et al., 2017). On the basis of this evidence, together with television and magazine advertisements, information obtained on the Internet, articles in the lay press, and the recommendations of their physicians, a large proportion of the Western population takes a variety of vitamin, mineral, and herbal supplements daily in the hopes of promoting good health, preventing chronic diseases (such as heart disease and cancer), limiting the ravages of aging, and ultimately extending life (Marik and Flemmer, 2012). Dietary supplements (DS) use among older adults is even higher, as National Health and Nutrition Examination Survey (NHANES) 2011-2012 reported that up to $72 \%$ of individuals aged 65 years and older use supplements. In addition, among older adults surveyed in NHANES 2011-2012, $21 \%$ reported using four or more supplements daily (Harris et al., 2017). The continued use and popularity of DS in recent years may be due to various factors, including perceived health-promoting properties, fear of adverse events associated with prescription medications, cost of prescription medications, over-the-counter availability of DS, and belief that DS are natural and therefore safe to use (Walrand, 2018). Although some DS may indeed have the expected benefits on human health, it would be unwise to assume that they are all efficacious and safe to use. 
In the following sections, we will define what are DS, when is it beneficial to take them and what risks might occur with their (unsupervised) use.

\section{Methods}

PubMed database and the world wide web were searched with mesh terms "prehranska dopolnila« - »dietary/food supplements«, »starostniki« - »elderly«, »zakonodaja« - »legislation«, »interakcije« - »interactions« and their combinations. English language articles published after 2000 were included in narrative review, as well as electronic sources regarding legislation in Slovenia and Europe.

\section{Results and discussion}

\section{Definition, regulation of DS and problematic related to it}

A DS is defined according to the National Institutes of Health (n.d.) as a product that is intended to supplement the diet, which contains one or more of the following dietary ingredients: vitamins, minerals, herbs or other botanicals, amino acids, and other substances or their components. It is intended to be taken by mouth as a pill, capsule, tablet, or liquid form. DS are not meant to be and therefore cannot be represented as a conventional food item or a sole item of a meal or diet. They are also not intended to "treat, diagnose, prevent, or cure disease" and must be identified as a DS on the label (Harris et al., 2017). In the European Union (EU), DS are regulated as foods under the The Food Supplements Directive (FSD) Directive 2002/46/EC, which establishes a definition for DS, a list of allowable vitamins and minerals, and sets labelling requirements. Substances other than vitamins and minerals are not directly covered by the directive, and rules regulating these substances are still governed by individual EU member states. The Directive calls for the establishment of harmonized minimum and maximum dosage amounts; however, this has yet to be done and remains a competence of EU member states (Sovereign Silver, n.d.). FSD allows the Member States to implement only a notification procedure by which DS are reported to the authorities at the time they are put on the market. However, some Member States have not considered it necessary to introduce a notification obligation (Coppens, 2018). In Slovenia, the legal requirements on DS are determined in Rules on food supplements - Pravilnik o prehanskih dopolnilih (Official Gazette of the Republic of Slovenia (RS) - Uradni list RS, No. 66/33) issued by the national Ministry of Health. From the 5th of August 2013, the Ministry of Health no longer accepts new applications for DS and no longer keeps a list of DS currently marketed in RS. DS are classified as foods and must comply with an umbrella law on food, which states that all DS put on the market, must be safe to use and not contain substances in a form or amount that could pose a risk for human health. DS can be put on a market only by the food business operators, that have the appropriately registered food plant in the RS. The compliance with the food law on all the levels from manufacturing, dis- 
tribution and marketing is performed by the Health Inspectorate of the RS (Ministrstvo za zdravje, 2014). Safety and efficacy of DS in the EU are evaluated by the European Food Safety Authority (EFSA), an entity set up in January 2002 as an independent source of scientific advice that produces opinions which then are used by the European Commission to adopt legislation. In Slovenia, National Institute for Public Health (Nacionalni inštitut za javno zdravje) has joined European linkage called Nutrivigilance, which is intended to identify the possible risks related to DS consumption and prevention of them. The main purpose of nutrivigilance is to ensure the information flow between the consumers, food business operators and regulatory institutions. It includes raising awareness and reporting of possible adverse events (Nacionalni inštitut za javno zdravje, n.d.). Nonetheless, legislation around DS is much more loose compared to drugs and regulation of quality and safety is mostly post-market, whereas efficacy of DS is not being verified (Harris et al., 2017).

\section{Benefits from taking DS}

Nutrient deficiencies and malnutrition among the older adult population are a concern and may be reduced by supplementation (Gariballa, 200o). DS can play a role in optimizing nutrient levels among older adults who have poor nutrient intake due to decreased appetite, dental issues, etc., are at risk of malnutrition, or experience nutrient depletions from medications. Approximately $34 \%$ of individuals over the age of 65 are nutritionally deficient in protein, calories, and multiple micronutrients. Specific micronutrients of concern include those that are consistently found to be deficient in the diet and/or nutrients for which the digestion, absorption, or metabolism declines with age (such as vitamins A, C, D, B6, B12, and folate plus calcium, zinc, and magnesium). Supplementation may also be beneficial among older adults prescribed medications that reduce or interfere with the absorption of nutrients, such as statins, antacids, antidepressants, antibiotics, oral hypoglycemic medications. Proton pump inhibitors have been associated with nutrient deficiencies such as vitamin B12, vitamin $\mathrm{C}$, calcium, iron, and magnesium and metformin has been shown to cause vitamin B12 and folate malabsorption, specifically when used at higher doses and for extended periods of time (Harris et al., 2017).

In general, various DS are used by older people mainly in the expectation of reducing the risk of developing cancer, cardiovascular diseases, cognitive impairment, or skeletal muscle loss (Walrand, 2018). The most common DS taken among elderly, can be grouped according to their chemical nature as follows: vitamin and mineral supplements, omega-3 polyunsaturated fatty acids (PUFAs) supplements, protein supplements and plant-based supplements.

Many clinical studies aimed to investigate positive effects of the administration of antioxidant vitamins and their possibility to decrease cell oxidative damage, thereby decreasing the incidence of degenerative diseases and cancer (Walrand, 2018). In a longitudinal population-based study high vitamin E intake was associated with better cognitive performance during aging (Morris et 
al., 2002). Vitamin D and/or calcium are important modifiable factors associated with optimal bone health. Kahwati et al. (2018) compiled 11 randomized controlled trials, and concluded that compared with placebo, supplementation with vitamin D decreased total fracture incidence. Several clinical studies also investigated multivitamin supplements intake and possible prevention of atherosclerosis and cardiovascular disease. These studies have pointed to potential reductions in the risk to develop age-related diseases among older people who reported long-term use of multivitamins (Walrand, 2018).

Both randomized clinical interventions and observational studies highlight the protective effects associated with diets supplemented with fish oil and omega-3 PUFA, particularly the longer chain fatty acids, eicosapentaenoic acid (EPA), and docosahexaenoic acid (DHA). EPA and DHA supplementations have been extensively studied therapeutically in a wide variety of disease conditions, though principally cardiovascular diseases (Walrand, 2018). Beside fewer cardiovascular deaths due to higher plasma levels of omega-3 PUFAs, recent studies suggest that they may be also associated with cognitive status in older people. Ammann et al. (2017) have reported that higher levels of blood DHA+EPA may help protect against the development of dementia in older women. Furthermore, omega-3 PUFAs may also modulate physical performance in the elderly, as has been shown that they enhance muscle anabolic responses (Lalia et al., 2017).

Milk protein consists of whey - a fast digested protein with a large amount of leucine, which has been suggested as being responsible for enhanced ability to stimulate muscle protein anabolism. In a systematic review by Liao et al. (2017), it was confirmed that, dietary protein supplementation combined with exercise had a strong effect in preventing age-related muscle mass attenuation and leg strength loss in older people. Results from the study by Koutsofta et al. (2019) showed that combined protein administration through supplemental proteins for a period of up to 12 months may positively affect osteoporosis in postmenopausal women.

A prospective study comprising 1640 aged participants showed that persons with high dietary intake of flavonoids maintained better cognitive functions at the baseline and showed slower cognitive decline over a period of 10 years (Letenneur et al., 2007).

\section{Risks associated with DS use}

Although supplement use provides potential benefits by increasing nutrient intake, there are potential drawbacks. Firstly, the concurrent use of prescription medications and DS has become more common among older adults which increases the risk of potential drug-nutrient interactions. Of particular concern is polypharmacy, or the concurrent use of more than five prescription medications, which is common in elderly. The most problematic common herb with a very high risk of drug-nutrient interactions is St. John's wort (Hyperi- 
cum perforatum), which can increase metabolism of drugs processed through the $\mathrm{CYP}_{3} \mathrm{~A}_{4}$ enzymes, making up 50\% of all drugs. Other common potential drug-nutrient interactions include grapefruit (Citrus $\times$ paradisi), pomegranate (Punica granatum), goldenseal (Hydrastis canadensis), and black pepper (Piper nigrum) due to the inhibition of CYP450. Another common interaction can occur between anticoagulant medications such as warfarin and supplements such as cranberry (Vaccinium oxycoccos), garlic (Allium sativum), Ginkgo (Ginkgo biloba), coenzyme Q10, and fish oil/omega-3 fatty acids, due to increased risk of bleeding (Harris et al., 2017).

Secondly, although users tend to be motivated by putative health benefits, there is no clear evidence that the use of dietary supplements affects age-related chronic diseases and mortality (Walrand, 2018). While a considerable body of evidence has been gathered showing a positive impact of consuming some DS, some studies also reported contradictive results. Marik and Flemmer (2012) reviewed 63 randomized controlled trials that evaluated the benefits and safety of DS such as $\beta$-carotene, vitamin A, B6, B12, C, D, E, folic acid, calcium, selenium, omega-3 fatty acids, glucosamine and some herbs (Ginkgo, saw palmetto, milk thistle). No benefit was recorded in 45 studies, with ten of these showing a trend toward harm and two showing a trend toward benefit. Four studies reported harm, with an increased risk of cancer and cancer deaths in the Carotene and Retinol Efficacy Trial and the Norwegian Vitamin Trial II studies, and an increased risk of fractures in the two studies that investigated high-dose once-yearly vitamin D. The Nutritional Cancer Prevention Study (selenium supplementation) demonstrated both benefit (less cancer) and harm (increased risk of type 2 diabetes). The lower risk of cancer with selenium supplementation, however, was not confirmed in the much larger selenium and Vitamin E Cancer Prevention Trial. Similarly, the Calcium Polyp Prevention Study demonstrated both a benefit (reduced fractures and reduced polyps) and harm (increased acute myocardial infarction). A beneficial outcome was reported in only three studies with omega-3 fatty acids and in six studies with vitamin $\mathrm{D}$, which appeared to be dose dependent.

\section{Conclusions}

As there are a lot of things that need to be taken into consideration to ensure safe and reasonable supplementation in older patients, it is recommended that they seek professional consultation before starting a new supplement regimen. Supplement recommendations by healthcare practitioners should be tailored to each individual patient with consideration of quality of diet, use of medications, and other medical/social factors. Ideally, nutrition screening should be conducted for every patient by a qualified provider, such as a registered dietitian nutritionist, in order to assess nutrient intake and risk of malnutrition. If supplementation is deemed beneficial, the quality, safety, and efficacy of the DS should be assessed and the best regimen for the given patient determined. 


\section{References}

AMMANN, E.M., POTTALA, J.V., ROBINSON, J.G., ESPELAND, M.A., HARRIS, W.S., 2017. Erythrocyte omega-3 fatty acids are inversely associated with incident dementia: Secondary analyses of longitudinal data from the Women's Health Initiative Memory Study (WHIMS). Prostaglandins, Leukotrienes, and Essential Fatty Acids, vol. 121, pp. 68-75. https://doi.org/10.1016/j.plefa.2017.06.006

COPPENS, P., 2018. Food Supplements in the European Union: the Difficult Route to Harmonization [online]. [viewed 8 August 2021]. Available from: https://www.raps.org/news-and-articles/news-articles/2018/7/food-supplements-in-the-european-union-the-diffic

GARIBALLA, S.E., 200o. Nutritional support in elderly patients. The Journal of Nutrition, Health \& Aging, vol. 4, no. 1, pp. 25-27.

HARRIS, S.R., MORROW, K., TITGEMEIER, B., GOLDBERG, D., 2017. Dietary Supplement Use in Older Adults. Current Nutrition Reports, vol. 6, no. 2, pp. 122-133. https://doi.org/10.1007/s13668-017-0198-6

KAHWATI, L.C., WEBER, R.P., PAN, H., GOURLAY, M., LEBLANC, E., COKER-SCHWIMMER, M., VISWANATHAN, M., 2018. Vitamin D, Calcium, or Combined Supplementation for the Primary Prevention of Fractures in Community-Dwelling Adults: Evidence Report and Systematic Review for the US Preventive Services Task Force. Journal of American Medical Association, vol. 319, no. 15, pp. 160o-1612. https://doi. org/10.1001/jama.2017.21640

KOUTSOFTA, I., MAMAIS, I., CHRYSOSTOMOU, S., 2019. The effect of protein diets in postmenopausal women with osteoporosis: Systematic review of randomized controlled trials. Journal of Women \& Aging, vol. 31, no. 2, pp. 117-139. https://doi.org/10.1080/o8952841.2018.1418822

LALIA, A.Z., DASARI, S., ROBINSON, M.M., ABID, H., MORSE, D.M., KLAUS, K.A., LANZA, I.R., 2017. Influence of omega-3 fatty acids on skeletal muscle protein metabolism and mitochondrial bioenergetics in older adults. Aging, vol. 9, no. 4, pp. 1096-1129. https://doi.org/10.18632/ aging.101210

LETENNEUR, L., PROUST-LimA, C., LE GOUGE, A., DARTIGUES, J.F., BARBERGER-GATEAU, P., 2007. Flavonoid intake and cognitive decline over a 10-year period. American Journal of Epidemiology, vol. 165, no. 12, pp. 1364-1371. https://doi.org/10.1093/aje/kwmo36

LIAO, C.-D., TSAUO, J.-Y., WU, Y.-T., CHENG, C.-P., CHEN, HUI-CHUEN, HUANG, Y.-C., CHEN, HUNG-CHOU, LIOU, T.-H., 2017. Effects of protein supplementation combined with resistance exercise on body composition and physical function in older adults: a systematic review and meta-analysis. The American Journal of Clinical Nutrition, vol. 106, no. 4, pp. 1078-1091. https://doi.org/10.3945/ajcn.116.143594 
MARIK, P.E., FLEMMER, M., 2012. Do dietary supplements have beneficial health effects in industrialized nations: what is the evidence? Journal of parenteral and enteral nutrition, vol. 36, no. 2, pp. 159-168. https://doi. org/10.1177/0148607111416485

MINISTRSTVO ZA ZDRAVJE RS, 2014. Napotki glede področja prehranskih dopolnil v Republiki Sloveniji in skladnosti tovrstnih izdelkov Z veljavno zakonodajo [online]. [viewed 8 August 2021]. Available from: https://www.gov.si/assets/ministrstva/MZ/DOKUMENTI/Preventiva-in-skrb-za-zdravje/varnost-zivil-in-hrane/napotki_s_podrocja_ prehranskih_dopolnil_2015.pdf

MORRIS, M.C., EVANS, D.A., BIENIAS, J.L., TANGNEY, C.C., BENNETT, D.A., AGGARWAL, N., WILSON, R.S., SCHERR, P.A., 2002. Dietary intake of antioxidant nutrients and the risk of incident Alzheimer disease in a biracial community study. Journal of American Medical Association, vol. 287, no. 24, pp. 3230-3237. https://doi.org/10.1001/jama.287.24.3230

NACIONALNI INŠTITUT ZA JAVNO ZDRAVJE, n.d. Varno uživanje prehranskih dopolnil in poročanje o neželenih dogodkih [online]. [viewed 8 August 2021]. Available from: https://www.nijz.si/sl/varno-uzivanje-prehranskih-dopolnil-in-porocanje-o-nezelenih-dogodkih-o

NATIONAL INSTITUTES OF HEALTH, n.d. Dictionary of Dietary Supplement Terms [online]. [viewed 4 June 2021]. Available from: https://ods. od.nih.gov/HealthInformation/dictionary.aspx

SOVEREIGN SILVER, n.d. How Dietary Supplements are Regulated in Europe [online]. [viewed 8 August 2021]. Available from: https://sovereignsilver. com/pages/how-dietary-supplements-are-regulated-in-europe

WALRAND, S., 2018. Dietary supplement intake among the elderly: hazards and benefits. Current Opinion in Clinical Nutrition and Metabolic Care, vol. 21, no. 6, pp. 465-470. https://doi.org/10.1097/MCO.00ooooooooooo512 